\title{
The Factors that Influenced Consumptive Behavior: A Survey of University Students in Jakarta
}

\author{
Aldo Enrico*, Ritchie Aron *, Weriyen Oktavia * \\ * President University, Department of Business Administration 2011, Jababeka, Cikarang 17550 Indonesia
}

\begin{abstract}
Nowadays, in big cities the consumptive behaviors among university students become common. However this fact indicates a negative impact for financial performance because students have not found their money yet. This journal is conducted with a purpose, to know what the factors that affect people's consumptive behavior are. This research journal is conducted in Jakarta, Indonesia, and the respondents are students from several universities that are located in Jakarta. The method that we are using is a quantitative research by spreading questionnaires. The amount of samples that we took in this research is 270. From the research, the authors conclude that Product Usage and Purchasing Power, social status, prestige and satisfaction is related to people's tendency to have consumptive behavior. Therefore, by knowing these factors, hopefully people will be able to suppress their consumptive behavior or help the people in our surroundings not to be consumptive.
\end{abstract}

Index Terms- Behavior, Consumptive, Prestige, Saving.

\section{INTRODUCTION}

$\mathrm{C}$ onsumptive behavior becomes one of the behaviors that cannot be separated from the daily life of the people not only in big country but also growing country such as Indonesia (Wahyningtyas, 2011). Consumptive behavior affects the life style of the people especially in the growing country because people in growing country are usually the consumer of the goods that are produces in big countries. (Why do Nations Export, 2013)

This phenomenon also impacts the students' life in university, students in present days have some additional expense for students' life such as Internet provider, copy lesson materials or books, and moreover students nowadays have Smartphone that need credit to activate its services (Wahyningtyas, 2011). University students, especially in big city like Jakarta also need to fulfill their desire and their social need (Campen, Gerlinger, \& Reusswig, 2005) by hangout in café and going to the mall. All of these activities make students to be more consumptive and make saving to be a thing that is not in students' priority list. However, saving is very important for the future because future is full of uncertainty (Secrets of Mind and Reality, 2009). Unexpected expense will hit student hard if student don't have any saving. For example: if you are a student who come from outside java island and suddenly get sick, they have to pay the medication. If the student doesn't have any saving he or she will not be able to afford the treatment. It will affect his or her study activity in university.
By knowing this problem that is stated above, the Authors hope that it will give more knowledge about factors that influences the consumptive behavior. This research can also be used for parents to encourage their children not to have a consumptive behavior and start to have saving. In University life, students have to manage their own spending, different with the junior high or senior high students whose money still manage by Students' parents.

This research was limited only in Jakarta because:

1) Jakarta has many recreation infrastructures such as malls, cafes, restaurants, theme parks, and nowadays emerge a new entertainment place, the karaoke places. All of that places encourage students to spent more money.

2) Jakarta has a lot of universities, especially universities which located near an Entertainment places. We will get many respondents for our researches.

This research was conducted by using quantitative analysis. The questionnaires were spread to state and private universities in Jakarta to find the data used for the researches. The respondents were the university Students, which are randomly chosen without seeing the grade (1st year, 2nd year, so on).

This research paper separated in 4 parts. First one is the abstract and introduction of what is the consumptive behavior. The second part consists of the literature review of research topic. Third part contains the analytical review of the data from the questionnaire. Last part contains the conclusion of the research topic.

\section{LITERATURE REVIEW}

\subsection{Independent Variables}

Humans do the consumption activity everyday for living. Consumption is an activity using product or service to achieve maximum satisfaction. Human do consumption because they have their needs. Every person have their own needs. People usually make the products or ask for services to satisfy their needs. If they cannot produce their own products or ask another person to give them service, they cannot fulfill their needs. People from the old days trade their products in accordance to their needs by using the barter method. Nowadays, because all of our activities are related with money, people do not do barter anymore. People will have to purchase with money if they want to have a product or service to fulfill their needs. Therefore, indirectly the purchasing activity has become another comsumption activity. (Waluyo, 2008) 
In modern era, consumptive behavior among people grow quickly. People tend to buy more product than what they really needs. Consumptive behavior happen because human have a lot of desire. There are some factors that the writer consider as the variables that caused human to have consumptive behavior, there are:

\subsubsection{Fulfilling Desire}

As been said in Oxford Advanced Learner's Dictionary, 2000, The desire itself is not only for physical. Desire can also come from our mental. There are four basic mental desire that everyone have, there are: the desire to be treated as human, desire to gain control, desire to be consistent, and desire to have high prestige. In this research, the authors will be focused on the Physical desire, and the desire to have high prestige because those factors are considered more relevant to the research that the authors conduct.

\subsubsection{Purchasing Power}

According to Oxford Advanced Learner's Dictionary, 2000 , purchasing power is the money that people have to buy goods with. This explains that the bigger amount of money that people have, the bigger their purchasing power is. Big buying power means they can fulfill their needs and desire. However, as the authors have stated above that human desire are limitless, bigger purchasing power does not means that the person's desire will be easily satisfied and then they will not desire another things. Usually, if the people have bigger purchasing power, that means they are richer, and if they are richer, they usually have more prestige. If they have more prestige, they usually will not buy the cheaper products. Also, richer people could buy much more products.

\subsubsection{Product usage}

Product Usage is the time of the item being used until it can be used anymore (Aiguier, Bretaudeau, \& Krob, 2010). Product usage is different between one product and another product. The Duration, actual contact, frequency, and amount of product being used show the Product Usage (Karwowsk, Soares, \& Stanton, 2011). Every people have their own product usage period. One person can say that the product is not productive anymore while the other person says that the product is still usable.

\subsubsection{Social Status}

Peoples are living within society. They need each other to helping because they are social being. In society, we know all people have status based on their background live such as family, religious, education, economic. Social status is given by the people inside the society. According Oxford Advanced Learner's Dictionary, 2000, status is the legal position of a person. People have status when they have role in society. According to Pujiastuti status social means position give to people in society (PUJIASTUTI, 2007)

\subsubsection{Family Lifestyle}

A person's lifestyle is the person's pattern of living in the world as expressed in the person's activities, interest and opinion (Kotler, 2003). Every person have different lifestyle, Even in one family. However, usually the main factor that influenced a person's lifestyle is their family. Furthermore in his book, Kasali stated that people will tend to choose products, services, and activities based on what products, services, and activities can be related to their style. The morphing of somebody's lifestyle happens since they were little and affected by many aspects such as cultures, norms, neighborhood, friends, way of learning, personality, and family (Lantos, 2010). Therefore, in this research, family lifestyle will be questioned even more on the impact to consumptive behavior in a person.

\subsection{Relations and Hypothesis}

\subsubsection{Fulfilling Desire and consumptive behavior}

Human's desire, mainly the additional desire is the reason human have consumptive behavior. However, the main desire can also be the reason for human to have consumptive behavior, for example clothes. Human desire, naturally will not be over. Even if someone already fulfill their desire, another desire will come again. Therefore, the fulfilling desire of human will not be ended. Fulfilling the desires require a consumption, and this makes human have consumptive behavior. As stated above that human desire will never ends, therefore, the consumptive behavior in human will never ends too (Agustia, 2012).

$\mathrm{H} 1$ : fulfilling desire (X1) is affecting the consumptive behavior

\subsubsection{Purchasng power and consumptive behavior}

Furthermore, this definition can leads to the phenomenon of bigger consumptive behavior. It means that the more money that people got, they tend to be more consumptive. Nowadays, especially in urban or city area, parents are more generous to give their children their allowance. This leads to students given more money that they basically needs. The needs needs of the children are usually not so much, because usually they are still staying at their parent's house and still have treatment like place to stay and foods everyday from their houses that do not require any money. Being given more money makes them to spend their money more and make students nowadays more consumptive (Agustia, 2012).

H2: Purchasing power (X2) is affecting Consumptive behavior

\subsubsection{Usage of Product and Consumptive behavior}

Every people have their own perspective about how long the product still can be used. We related this independent variable (Product Usage) with the Dependent variable (Consumptive behavior) because the varieties of product usage make some people to be consumptive. For example: nonConsumptive people tend to use the Smartphone until it can be used anymore or broken. Consumptive people tend to buy another Smartphone while their Smartphone still can be used or fully functional (HOTPASCAMAN, 2008, pp. 89-95).

$\mathrm{H} 3$ : The usages of the product (X3) influence the Consumptive behavior

\subsubsection{Social Status and Consumptive Behavior}

Usually, people have higher status has more purchasing power so we can conclude relationship between social status with behavior consumptive very strong. For example: when the price of goods decrease, people who have higher status still to buy product with higher price. This phenomena happen because rich people or high status tend to show their prestige which different with another status (HOTPASCAMAN, 2008, pp. 89-95).

\section{H4: Social Status (X4) influence the Consumptive behavior}

\subsubsection{Family Lifestyle and Consumptive behavior}

As stated above, the lifestyle of a person is affected by their surroundings, and the authors consider that family is the biggest aspect that impacted the consumptive behavior of our respondents, since our respondents will be college students that are mostly still close to their family. The likeliness of their 
parents to go shopping will affect the children's lifestyle to have more consumptive behavior (HOTPASCAMAN, 2008).

H5: Family lifestyle (X5) affected Consumptive Behavior

\section{RESEARCH DESIGN}

\subsection{Sampling}

The target populations for this research consist of college students in Jakarta. The unit of analysis was the individual student. The sampling method that we used in order to collect the data from the respondents that are use for our research are unrestricted or simple random sampling. The authors used this method because the authors did not make any restriction of the respondent of this research beside college student in Jakarta. Therefore, any college student in Jakarta can be chosen as the respondent of this research regardless their batch, age, and academic score. As long as the student is listed in university in Jakarta, they can be the respondent.

\subsection{Data Collection}

In research methodology, the authors use personally administered questionnaires' method that established rapport and motivate respondent. The authors use this method because this method can collect data faster compare with others method. This method also provides almost $100 \%$ rate of respond compare with other method such as mail questionnaire and electronic questionnaire (Sekaran \& Bougie, 2009). The data will be collected within 3 weeks starting from 20 October 2013 until 6 November 2013. The authors appreciates the respondent who willing to fill the questionnaire.

\subsection{Measures}

Direct single question used to gather all demographic variables such as age, sex, semester, Father's and mother's job, incentive/month, expense/month, and saving/month. To conduct regression model, authors have to use Normality test, Heterocedasticity, and multicollinearity; but in this research the authors only use Normality test to check the validity of the questions. For Reliability of the assumption, authors sees the result of Cronbach's Alpha in SPSS. If the Cronbach Alpha value is bigger than 0.7 , it means the data is reliable, otherwise the data is unreliable (Field \& Miles, 2010).

\section{DATA ANALYSIS}

\subsection{Demographic}

The authors collected the data from 270 respondents which are university students in Jakarta, the demographic data of the respondents that the authors will include in this section include: age, gender, semester, incentive/month, expense/month, and saving/month.

\subsection{Instrument Test}

In order to get the result of the research, Authors conducted two tests which are Validity test and Reliability test. Authors does not use Multiple Regression test because there are no dependent variable.

\subsubsection{Validity Test}

The authors use validity test to know the whether the Variables are valid or not. The Authors use KMO (KaiserMeyer-Olkin) $\geq 0.5$ to see whether the variables are valid or not (Warnaars \& Pradel, 2007).

KMO and Bartlett's Test

\begin{tabular}{|c|c|c|}
\hline \multicolumn{2}{|c|}{ Kaiser-Meyer-Olkin Measure of Sampling Adequacy. } & $\begin{array}{l}.745 \\
1096.680\end{array}$ \\
\hline \multirow[t]{2}{*}{ Bartlett's Test of Sphericity } & Df & 78 \\
\hline & Sig. & .000 \\
\hline
\end{tabular}

Validity Test Result for each variable

Communalities

\begin{tabular}{|l|l|l|l|}
\hline No & Variables & Extraction & Result \\
\hline a1 & Pleasure in buying & Valid \\
a4 & Influence of advertising & .817 & Valid \\
b3 & Buying decision regarding financial power & .598 & Valid \\
b4 & Buying product using own money or saving & .522 & Valid \\
c1 & Buying product without using it & .670 & Valid \\
c2 & Buying product for collection (different color and shape with same & .633 & Valid \\
d4 & function) & .653 & Valid \\
d5 & Buying product that usually used by mid-high level person & Valid \\
d6 & Fuying product that have good reputation & Valid \\
d8 & Buying expensive product to show prestige & .723 & Valid \\
e2 & Family always remind to buy good product regarding the quality & .705 & Valid \\
e3 & Parents give freedom to me to use my own money & .831 & Valid \\
e4 & Family like to shopping & .769 & Valid \\
\hline
\end{tabular}


Those variable is valid because it has value more than or equal to 0.5 . Since the KMO $\geq 0.5$ is valid, it can pass the validity test and ready to test the reliability.

Total Variance Explained

\begin{tabular}{|c|c|c|c|c|c|c|c|c|c|}
\hline \multirow[t]{2}{*}{$\begin{array}{l}\text { Compo } \\
\text { nent }\end{array}$} & \multicolumn{3}{|c|}{ Initial Eigenvalues } & \multicolumn{3}{|c|}{$\begin{array}{l}\text { Extraction } \\
\text { Loadings }\end{array}$} & \multicolumn{3}{|c|}{ Rotation Sums of Squared Loadings } \\
\hline & Total & $\begin{array}{l}\% \text { of } \\
\text { Variance }\end{array}$ & $\begin{array}{l}\text { Cumulativ } \\
\text { e } \%\end{array}$ & Total & $\begin{array}{l}\% \\
\text { Variance }\end{array}$ & of $\begin{array}{l}\text { Cumulative } \\
\%\end{array}$ & Total & $\%$ of Variance & Cumulative \% \\
\hline 1 & 3.851 & 29.624 & 29.624 & 3.851 & 29.624 & 29.624 & 2.910 & 22.385 & 22.385 \\
\hline 2 & 1.762 & 13.557 & 43.181 & 1.762 & 13.557 & 43.181 & 2.104 & 16.186 & 38.571 \\
\hline 3 & 1.655 & 12.732 & 55.913 & 1.655 & 12.732 & 55.913 & 1.676 & 12.892 & 51.463 \\
\hline 4 & 1.154 & 8.874 & 64.787 & 1.154 & 8.874 & 64.787 & 1.615 & 12.427 & 63.889 \\
\hline 5 & .905 & 6.962 & 71.749 & .905 & 6.962 & 71.749 & 1.022 & 7.860 & 71.749 \\
\hline 6 & .759 & 5.839 & 77.589 & & & & & & \\
\hline 7 & .564 & 4.335 & 81.924 & & & & & & \\
\hline 8 & .558 & 4.290 & 86.214 & & & & & & \\
\hline 9 & .453 & 3.485 & 89.699 & & & & & & \\
\hline 10 & .369 & 2.840 & 92.540 & & & & & & \\
\hline 11 & .344 & 2.643 & 95.183 & & & & & & \\
\hline 12 & .340 & 2.615 & 97.798 & & & & & & \\
\hline 13 & .286 & 2.202 & 100.000 & & & & & & \\
\hline
\end{tabular}

Extraction Method: Principal Component Analysis.

In order to pass the validity test, the percentage of cumulative in Rotation Sums of Squared Loadings must be greater than $60 \%$. Since the percentage cumulative of Rotation
Sums of Squared Loadings is greater than $60 \%(71.749 \%)$ the authors assume that the variable is passing the validity test (Warnaars \& Pradel, 2007).

\begin{tabular}{|c|c|c|c|c|c|}
\hline & Com & & & & \\
\hline & 1 & 2 & 3 & 4 & 5 \\
\hline $\begin{array}{l}\mathrm{a} 1 \\
\mathrm{a} 4 \\
\mathrm{~b} 3 \\
\mathrm{~b} 4 \\
\mathrm{c} 1 \\
\mathrm{c} 2 \\
\mathrm{~d} 4 \\
\mathrm{~d} 5 \\
\mathrm{~d} 6 \\
\mathrm{~d} 8 \\
\mathrm{e} 2 \\
\mathrm{e} 3 \\
\mathrm{e} 4\end{array}$ & $\begin{array}{l}.757 \\
.665 \\
.794 \\
.777 \\
.688\end{array}$ & $\begin{array}{l}.734 \\
.798 \\
.777\end{array}$ & $\begin{array}{r}.899 \\
\\
.893 \\
\\
.893\end{array}$ & 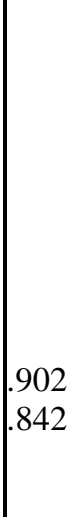 & 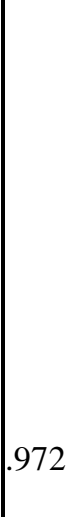 \\
\hline
\end{tabular}

The authors will test the reliability test base on the component in the Rotated Component Matrix. For the first Component the variables are a4, b3, b4, c1, c2. Second components are d4, d5, d6. Third components are a1 and e4. Fourth components are $\mathrm{d} 8$ and e2. The last component only consists of one variable. The further research, which is reliability test based on Cronbach's Alpha cannot be conducted on a variable with only 1 variable, therefore the authors will not conduct the reliability test for fifth component.

\subsubsection{Reliability Test}

Reliability is concerned with estimates of the degree to which a measurement is free of random or unstable error. To 
measure reliability, the authors used Cronbach's Alpha Coefficient. If the Cronbach's Alpha value is bigger than 0.7 , it means the data is reliable, otherwise the data is unreliable (Field \& Miles, 2010).

Reliability test for Components

Reliability Statistics

\begin{tabular}{|l|l|l|}
\hline Components & Cronbach's Alpha & N of Items \\
\hline 1 & .824 & 5 \\
\hline 2 & .745 & 3 \\
\hline 3 & 770 & 2 \\
\hline 4 & .720 & 2 \\
\hline
\end{tabular}

The Cronbach's Alpha of the components in this research are all $\geq 0.7$, therefore all the components in this research are reliable. Also, all of the Cronbach's Alphas had been maximized so that deleting any variables in each component could not change the Cronbach's Alpha to become bigger.

\section{CONCLUSION AND RECOMMENDATION}

\subsection{Conclusion}

Based on the research that the authors have conducted to 270 respondents, the authors conclude the entire variable into 5 dominant factors that had influence to their consumptive behavior.

\section{Product Usage and Purchasing Power}

The variance of initial Eigenvalues shows that the first factor has $29.624 \%$ of $71.749 \%$. That shows fulfilling desire is the most dominant factor that influences the consumptive behavior. Base on the question number 1 (variable 1) in the fulfilling desire section, the authors can see majority select number 3 (149 choices) and 4 (73 choices) which are agree and strongly agree. The question refers to the likeliness to spend money to buy something or to buy product that useful and product that suitable with their purchasing power. Question number 4 (variable 4) also show the same fact that when people buy a product they tend buy another product. It showed in the questioner where the majorities choose number 3 and 4 (138 and 64 choices). Product usage and purchasing power (H1) is affecting the Consumptive Behavior. Therefore, authors' hypothesis $1(\mathrm{H} 1)$ is accepted.

\section{Social Status}

The variance of initial Eigenvalues shows that the second factor has $13.557 \%$ of $71.749 \%$. This value shows that social status has a big role in creating the consumptive behavior. To maintain social status people become consumptive.

\section{Satisfaction}

The variance of initial Eigenvalues shows that the third factor has $12.732 \%$ of $71.749 \%$. As the third biggest percentage, satisfaction becomes one of the key factor of creating Consumptive behavior. In question number eleven we can see that majority choose agree and strongly agree.

Satisfaction (H3) is affecting Consumptive Behavior. Therefore, authors' hypothesis $3(\mathrm{H} 3)$ is accepted.
4. Prestige

The variance of initial Eigenvalues shows that the fourth factor has $8.874 \%$ of $71.749 \%$. Prestige also become one of the factor that creating consumptive behavior. To maintain the prestige, people become more consumptive. Question number 19 shows that majority choose agree and strongly agree in respond to the question.

Compare with another journal conducted by HOTPASCAMAN.S. All of the variables are accepted and it related each other. So we can conclude this result of this research has the similarity with the result of research conducted by HOTPASCAMAN. The difference is in authors result, the family lifestyle is rejected. Family lifestyle hypothesis is rejected meanwhile in HOTPASCAMAN result the hypothesis is accepted.

\subsection{Suggestion}

5.2.1. For the university students

The authors hope that by knowing the factors that influenced consumptive behavior that the authors have shown in this research, the students can be more aware about the consumptive behavior. The authors conduct this research in hope that the students can minimize their consumptive behavior by knowing the factors that triggered it. The authors also hope that the students can be more aware about the importance of savings. As we can see in the demographic part of chapter 4 , in the savings graph and table, it is shown that most of the respondents do not have any savings or only a few amounts of cash from their allowance, even if they have allowance above Rp 2,500,000 a month. Students really should have some money for them to save; besides they can buy products beyond their buying power if they save money, but it also can train them to be not too consumptive later in the future if they are accustomed to save some of their allowance.

\subsubsection{For future research}

For future research, the authors hope that the respondents can be added because Jakarta is a big city and the respondents could be more than what the authors have conducted. Also the location could be bigger than Jakarta, such as Jabodetabek (Jakarta, Bogor, Tangerang, Bekasi) or Java Island. Future research could also increase the number of factors and questions that being used in conducting the research. A future research also can make the cosncern deeper, as the authors only put concern in the consumptive behavior can make people will not be able to save money. This topic is very vast therefore expanding the topic for the future research is much recommended.

\section{ACKNOWLEDGMENT}

First of all, the authors want to thank God, for the blessings that the authors received so that the authors are directed to the correct path and can finish this proposal on time. This research would have been near impossible to do without guidance and support whether it is moral or financial from our parents. Moreover, the authors would like to thank friends and participants of questioners who gave their time and support through the hardest time. The authors also like to give thank you 
to Mr. Suresh Kumar as advisor, thanks for support, advice, teaching and guidance that have been given in the making process of this proposal and research.

\section{Cikarang,October 222013}

The Authors

\section{REFERENCES}

[1] Agustia, R. S. (2012). Gambaran Perilaku Konsumtif Siswa-i Sekolah Menengah Atas "International Islamic Boarding School Republic of Indonesia" (SMA IIBS RI).

[2] Aiken, L. S., West, S. G., Cohen, J., \& Cohen, P. (2013). Applied Multiple Regression/Correlation Analysis for the Behavioral Sciences. Routledge.

[3] Aiyer, A. (2007). The Allure of The Transnational: Notes on Some Aspect of the Political Economy of Water in India. 640.

[4] Campen, H. L., Gerlinger, K., \& Reusswig, F. (2005). Changing Global Lifestyle and Consumption Patterns:The Case of Energy and Food. Reusswig, 1.

[5] Charles H. Zastrow, K. K.-A. (2012). Understanding Human Behavior in the Social Environment. In K. K.-A. Charles H. Zastrow, Understanding Human Behavior in the Social Environment (p. 3). Cengage Learning.

[6] Dunung, S. P., \& Carpenter, M. (2011). International Business v1.0. Flat World Knowledge.

[7] Field, A., \& Miles, J. (2010). Discovering Statistics Using SAS. Sage.

[8] HOTPASCAMAN. (2008). Hubungan Antara Perilaku Konsumptif Dengan Konformitas Pada Remaja. pp. 89-95.

[9] Karwowsk, W., Soares, M. M., \& Stanton, N. (2011). Human Factors and Ergonomics in Consumer Product Design. In W. Karwowsk, M. M. Soares,
\& N. Stanton, Human Factors and Ergonomics in Consumer Product Design: Uses and applications (p. 522). CRC Press.

[10] Kotler, P. (2003). Marketing Management. Pearso $\mathrm{n}$ Education International.

[11] Lantos, G. P. (2010). Consumer Behavior in Action: Real-Life Applications for Marketing Managers. M.E. Sharpe.

[12] Secrets of Mind and Reality. (2009). Retrieved october 4, 2013, from mindreality: http://www.mindreality.net/the-reasons-why-it-important-tosave-money

[13] Sekaran, U., \& Bougie, R. (2009). Research Methods For Business A Skill Building Approach. Chichester, West Sussex: John Wiley \& Sons Ltd.

[14] Wahyningtyas, P. (2011, August 1). The Consumptive Behavior of Indonesian Teenagers. Retrieved October 4, 2013, from http://salitaviki.blogspot.com/2011/08/consumptive-behaviour-ofindonesian.html

\section{AUTHORS}

First Author - Aldo Enrico, President University, Department of Business Administration 2011, Jababeka, Cikarang 17550 Indonesia, Aldoenricoo@gmail.com

Second Author - Ritchie Aron, President University, Department of Business Administration 2011, Jababeka, Cikarang 17550 Indonesia, Ritchie_aron@yahoo.com.sg Third Author - Weriyen Oktavia, President University, Department of Business Administration 2011, Jababeka, Cikarang 17550 Indonesia, Weriyen.oktavia@gmail.com 